Visit us - www.researchjournal.co.in DOI : 10.15740/HAS/IRJAES/7.2/175-177

International Research Journal of Agricultural Economics and Statistics

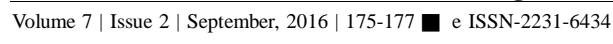

\title{
Research Paper Economic study of constraints and suggestions faced by the farmers in tomato production in Kolar district of Karnataka
}

See end of the paper for authors' affiliations

Correspondence to :

\section{J.L. KATKADE}

Cost of Cultivation

Scheme, Vasantrao Naik

Marathwada Krishi

Vidyapeeth, PARBHANI

(M.S.) INDIA

Paper History :

Received : 27.12.2015;

Revised : 17.07.2016;

Accepted : 15.08.2016

\begin{abstract}
Organic farming follows the principle of circular causation and has emerged in response to questions on health, environment and sustainability issues. Although India occupies second position in terms of number of certified organic farms $(44,926)$, it is $13^{\text {th }}$ in terms of area under organic farming representing only 0.3 per cent of total agricultural lands. This scenario appears poor compared to many other countries. Farmers apprehension towards organic farming in India is rooted in nonavailability of sufficient organic supplements, bio fertilizers and local market for organic produce and poor access to guidelines, certification and input costs. Capital-driven regulation by contracting firms further discourages small farm holders. An integrated effort is needed from government and nongovernment agencies to encourage farmers to adopt organic farming as a solution to climate change, health and sustainability issue.
\end{abstract}

KeY Words : Organic farmers, Constraints, Suggestions

How To Cite This PAper : Shelke, R.D., Katkade, J.L. and Jadhav, V.B. (2016). Economic study of constraints and suggestions faced by the farmers in tomato production in Kolar district of Karnataka. Internat. Res. J. Agric. Eco. \& Stat., 7 (2) : 175-177, DOI : 10.15740/HAS/IRJAES/7.2/175-177. 